\title{
Lay litigants' access to legal information in libraries
}

\author{
Angela Blake \\ MLIS Student \\ Victoria University of Wellington
}

June 2006

Submitted to the School of Information Management, Victoria University of Wellington in partial fulfilment of the requirements for the degree of Master of Library and Information Studies

h

AS741

VUW

A55

B636

L 


\section{Acknowledgments}

Thanks to the librarians who gave so freely of their time and knowledge during the interviews. Thanks also to Shauna for her invaluable assistance, to Amelia, Julia and Sarah, and to my supervisor Alastair Smith for his suggestions and advice. 


\begin{abstract}
This study examines the availability and accessibility of legal information for lay litigants - those people who have chosen to represent themselves in legal proceedings. It looks specifically at the information held in libraries and whether these libraries and the information held in them can be accessed by lay litigants.

Although this study looks at the ability of lay litigants to access legal information, it also discusses legal information access by the public in general. Distinctions have however been drawn between those seeking general legal information and lay litigants

The overall purpose of this research is to establish the current levels of access to information that lay litigants have, and whether the current situation is adequate and tenable. Principles and policies such as that of equal access to the law and the New Zealand government's commitment towards open government; enabling online access and its e-policy have been taken into consideration in evaluating whether the current situation is sufficient. Distinctions have also been drawn between those seeking general legal information and lay litigants.
\end{abstract}

Key words: lay litigant; legal information; access; availability; libraries 


\section{Contents}

Introduction

Problem Statement

Definition of terms

Limitations of the study

Hypotheses

Biases of the researcher

Literature review

i. Electronic publishing

ii. Public access to legal and governmental information

iii. Electronic Access

22

iv. Print Resources

25

v. Legislation

27

vi. Case law

vii. Conclusion

Methodology

Population

Data collection

Method of data analysis

Ability to replicate study

Discussion

Legal holdings

Staff numbers coming into contact with lay litigants

Policies regarding access to legal information

Types and numbers of inquiries

i. Types of enquiries

ii. Number of inquiries

iii. Ability to answer inquiries

Other ways libraries assist lay litigants 
Bibliography

Appendix 1: Interview questions

Appendix 2: Cover letter to interviewees

Appendix 3: Consent form 


\section{Introduction}

"In a modern state committed to upholding the rule of law it is... a cornerstone... that for citizens to comply with the law they must know what the law is" (Parliamentary Counsel Office 2005, 10).

The principles of equal access to the law and of ignorance being no defence to any breach of the law are well known. Less often quoted is the corollary to this, namely that for citizens to be able to comply with the law, they must be able to discover what the law requires and allows. There is an increasing need for awareness of the law as it permeates more and more areas of our lives. Employment contracts, family and custody issues, tenancy disputes and business transactions are just some of the situations that are controlled by legislation. The growth in the amount of legislation passed, the frequency with which Acts are amended and the growing complexity of legislation all contribute to make this need to stay informed difficult to satisfy.

Closely aligned to the above principles is the right that any person has to defend themselves in court, as opposed to being represented by a lawyer. Again, this right is balanced by a responsibility - namely that of the state to enable people to defend themselves by making the means to do so - i.e. legal information - available to them.

Traditionally, accessing legal information has meant going to a library to use the volumes of statutes and regulations, law reports, journals, books and looseleaf texts. However, with the recent proliferation in legislation and court decisions as well as the increase in the number of secondary resources being published, and a growing demand for legal information, accessing legal materials has become more problematic.

There are three problems that lay litigants face when trying to access relevant legal information. The first is the lack of available legal information. Legal information is 
available from a variety of sources - community law centres, citizen's advice bureaux, various government agencies, libraries and lawyers. Substantial holdings of legal information resources - such as law report series, statutes and regulations and comprehensive journal holdings - are less easy to come by. Guides to the procedures and rules of court, the process of litigation or even where to begin when attempting to research a legal problem for the layperson simply do not exist.

The information that is currently published - resources that are mostly aimed at practitioners such as law reports or journals - are not widely held by libraries or other information centres, especially not by such institutions that are open to the public. This is the second problem that lay litigants face - difficulty in accessing the information that is available. Specialist law libraries in New Zealand tend to be either private libraries or university libraries. Unlike Canada, the United States or Australia, there are very few libraries in New Zealand whose sole focus is on legal materials, and there are no public law libraries. The university law libraries are probably the closest New Zealand has, with most being open to in-house use from members of the public. However, the issuing of books and use of databases is not permitted (often due to license agreements as well as the extra demand this would place on systems that are primarily there for students), and the ability of reference staff to assist the general public may be curtailed by other demands on their time from staff and students. There are five university law libraries in New Zealand, with two other universities holding a good legal collection in their libraries. This does mean that for those outside the geographical area of each library that the pool of accessible resources is much narrower. Another complicating factor for lay litigants attempting to access information from law libraries is the way that law librarians deal with reference questions and inquiries. In a general reference situation the librarian is usually seeking to provide an answer to a question. Law librarians tend to help users identify and locate resources that may answer their inquiry, rather than providing an 
answer to a question. This is due to several reasons, especially the nature of the law and the need to interpret it, and also to avoid any possibility of unauthorised practice of the law. This situation can cause lay litigants and other users, who are often expecting answers and/or advice, frustration. It is an important point to clarify early on.

Other organisations that provide legal information such as the Citizens' Advice Bureaux or the Community Law Centres usually have to deal with funding issues as well as trying to cover a broad spectrum of concerns with what they do purchase. Legal information produced by parliament, such as statutes, or that which is funded by government, such as case law, can also be difficult to access. The rate at which legislation is being passed by the New Zealand parliament has increased markedly over the past twenty years. In addition, the constant amendments to many existing pieces of legislation make it imperative to have access to the most up-to-date version of the legislation. There has also been huge growth in not just the number of court decisions being issued, but perhaps more importantly, in the use of unreported judgments in court proceedings. These are probably the most difficult type of legal material to obtain. Earlier judgments, if available at all, are generally only held in law society libraries or in private collections in both cases only as hard copy reference or closed reserve items. These cases need to be requested and it can be difficult to find indices or references to them, or where they are held. More recent decisions are generally (but not always) available from proprietary databases or law society libraries. Accessibility can often be dependent upon which judge has heard a case, and which court a case has been heard in.

Unlike most of our common law neighbours, there is no freely available electronic access to court decisions in New Zealand. Whereas jurisdictions like Australia, Canada and the United States have made decisions available online (from both the federal and state or 
provincial courts) apart from cases from the recently established Supreme Court, there is no system or site that makes any kind of comprehensive collection of judgments freely available in New Zealand. The situation overseas is also increasing expectations of availability. Access to judgments, legislation and commentary on the law in comparable jurisdictions such as Australia and Canada is far superior to that in New Zealand. Australia especially sets the benchmark, with access to all federal laws and case law (and recent moves to make the online legislation official), most state laws and court decisions and a large and still growing collection of journals, official reports and suchlike available. The situation has in fact worsened recently, with the disappearance of the freely available Court of Appeal cases from Brookers website. Although these are meant to be appearing on the Ministry of Justice's website instead, this has not happened yet. Also contributing to this situation is the continuing delays to the Public Access to Legislation (PAL) project, which aims to provide freely accessible official versions of New Zealand legislative materials online. The project is now three years behind schedule. The most recent update from the PAL team now sees the system going live in late 2006/ early 2007. Whilst statutes, regulations and the like are available in most public libraries, concerns regarding ease of access, currency and completeness may easily become issues. The cost of updates and amendments to legislation can be another problem for libraries. Even the depository libraries, which receive all statutes and regulations enacted in New Zealand gratis, must pay for annotation of the statutes (an expensive service), or risk offering outof-date information.

Although much more information is made publicly available from government departments and agencies than has previously been the case, there are still areas that are not well covered. Legal information is one of these areas. Departments and ministries such as the Inland Revenue Department, the Ministry of Health and the Customs 
Department now make a wealth of information available in both hardcopy and especially via the internet. This makes the lack of legal information provided - such as court judgments and official versions legislative materials - much more noticeable. With the government's current focus on digital technologies and the gradual implementation of its e-strategy, this gap between what is and is not available and accessible is becoming more pronounced.

The advent of the internet has made the provision of information to wide audiences easier, whilst at the same time raising expectations of accessibility, availability and timeliness by users. There is also an expectation amongst many casual or novice users of online information that one can just push a button or enter a query into a search engine to find the information desired. This is far from being the case, but many individuals will assume that if they cannot find the relevant information online, it does not exist.

Legal information tends to be scattered. Legislation is published quite separately from the case law that interprets it, which is again published quite separately from the commentary that analyses these decisions. The structures and language of the law can be another barrier to both comprehension and finding relevant information for those not trained in this area. There have been moves made towards plain English legal drafting, and towards the simplification and de-formalisation of legal, and especially court processes. The most progress has been made with this in the Youth Court. However, there is still much in both the process of the law and in the legal literature that is confusing for the layperson.

The benefits of increasing and ensuring public access to legal information include: a more informed society with a greater awareness of their rights and responsibilities, the possibility of increased participation in a democratic society, particularly in the legislative process (which is already encouraged in New Zealand through public access to select 
committee hearings), an increased likelihood that completely unmeritorious cases will not be taken and a higher uptake of alternative dispute resolution methods- that preventative rather than corrective legal measures will be utilised. It facilitates a greater understanding of the legal system, including the legislative and court processes, and of the reasoning employed in judicial decisions. Increased access to case law can also enhance the accuracy of media reporting as demonstrated overseas, and to a degree by the Judicial Decisions of Public Interest site here in New Zealand: http://www.courtsofnz.govt.nz/from/decisions/judgments.html (Lake 2004, McMahon 1999). Whether it is likely that there will be high use of such resources (especially initially) should not be a prime concern. Policy issues of access and the right to know, as well as a longer-term vision and goal of accessible, reliable and discoverable information, are more important. (Greenleaf 1997, Lawn 2002, McMahon 1999).

There is very little awareness of the problems that lay litigants face when attempting to access legal information, especially from those who are in a position to improve this situation. This is the third problem that lay litigants face. To date, there has been no examination made of the state of lay litigants' access to legal information in New Zealand. Some attempts to facilitate lay litigants have been made, primarily by the Family Court. Guidelines and forms covering court procedure, applications for appointing a lay assistant and guides for judges and court staff have all been made available on the Family Court's website (http://www.justice.govt.nz/family/self-litigants/index.html). However there has been no systematic attempt to enable lay litigants. In overseas jurisdictions these matters have been addressed to varying degrees. In some ways this has compounded the problem as legal information from the United States or Australia is often far more accessible than similar resources from New Zealand. 
This lack of knowledge may be partly attributed to the relatively recent increase in the numbers of lay litigants in the legal system, and to the very recent acknowledgment of their presence in the legal system. However, there has also been very little examination made of the public's access to legal information in general. Access to various sources of law is seen as a concomitant responsibility to the belief that ignorance of the law is no defence (to any breach of the law). This balance is needed in order to ensure that individuals are not punished for an act or omission that they did not know was illegal. It is also necessary to ensure compliance with the law. With the increase in legislation being passed by the government, the rise in lay litigation and the exponential growth of electronic publishing, it becomes increasingly important to examine the extent of access lay litigants - and the public more widely - have to legal information.

The most recent figures available from Legal Services Agency show that from a pool of just over 69,000 applications for legal aid in the 2004/2005 financial year, 53,000 people were granted aid - approximately 77\% (Legal Services Agency 2005). Whilst this figure is high, it left around 16,000 individuals who (presumably) could not afford to hire a lawyer, and were thus faced with the choice of trying to represent themselves (and accessing relevant information for themselves), or leaving their claim unresolved. These figures do not include those who did not apply for legal aid and still chose to represent themselves in legal proceedings.

Whilst the primary audience for this research is intended to be librarians who deal with legal information, lay litigants, public enquiries or a mixture of all three, it may also be relevant to lay litigants and members of the general public, to other users of legal information and to other providers of legal information or advice. 


\section{Problem Statement}

Whilst there is more legal information available than previously, and in a wider variety of formats than ever before, the ability to access such information has not always developed in step with this growth. Thus even as more people are attempting to research their own legal situations, or to represent themselves in legal proceedings, the means by which to inform themselves of how to do so properly can be difficult to find. No examination of the access lay litigants have to the tools necessary to bring or defend a case in court, to act for themselves in a conveyancing matter or to establish what their rights and responsibilities are in a given situation has been undertaken. The purpose of this study is to establish a picture of the access that lay litigants currently have to legal information in libraries, in all formats that the library subscribes to or makes available to users.

\section{Objectives}

The objectives of this research are to:

- Identify current access levels for lay litigants

- Identify current policies in libraries regarding lay litigants' access to such information

- Identify the ways in which different libraries deal with lay litigants

- Identify any ways in which access could be improved

- Identify any emerging or best practices that libraries have developed in dealing with lay litigants' need for legal information 


\section{Definition of terms}

The definitions supplied below are how the terms should be read throughout this research project. They are not authoritative.

- Lay litigant: someone without any formal legal training, who is representing themselves in legal proceedings

- Member of the public: as opposed to a lay litigant: someone who is seeking more general legal information

- Access: the ability of being able to use, and/or find (information)

- Legal information: information necessary to undertake legal proceedings, such as statutory instruments, case law, rules of court, rules of procedure, and core secondary texts used to interpret and understand the law

- Primary resources: legislative instruments, such as statutes and regulations; case law (reported or unreported)

- Secondary resources: (usually) published materials that assist in interpreting primary legal resources; such as law commission reports, loose-leaf publications, textbooks and journal articles

\section{Limitations of the study}

This study is limited in that it only looks at the accessibility of legal information in libraries (including information held or linked to in an electronic format). It does not look at what information a lay litigant could discover for themselves online. The study does not attempt to examine these issues from a lay litigants' perspective, but rather from a library point of view. The focus is upon what legal information is able to be accessed, 
and also what problems are faced in gaining access to legal information. Questions asked were concerned with library holdings, the frequency and type of enquiries received, and any library policies for dealing with legal enquiries or lay litigants. This was to ensure that the study remained focused, and also to keep the focus upon legal information rather than particular issues that individuals may have. The study was undertaken in a large urban area, with staff from four types of library: academic; public; national and law society library interviewed. This is because of the limited time the researcher had available in which to complete the study, and also because it still enabled the researcher to compare results from a variety of libraries whilst maintaining some kind of link between each library. Whilst this does focus attention on a larger centre, it may be concluded that access in any smaller centre (which do not tend to have specialist law libraries) will certainly be no greater than in either of these cities, and very likely is worse. Whilst the pool of responses from which information is being gathered is smaller, it is also likely to be much richer in content and detail than if a larger sample of libraries had been surveyed, as well as still giving a representative sample to work with.

\section{Hypotheses}

The investigator held a number of assumptions or hypotheses before the research process began. These hypotheses were tested (and in some cases modified) by the results. They were:

- That lay litigants do encounter problems trying to access information

- That this is becoming a reasonably significant problem, both for lay litigants and therefore for others involved in the court process

- That the number of lay litigants is rising

- That access to primary legal information is most important for lay litigants 


\section{Biases of the researcher}

Particularly in qualitative research, as the researcher is the primary data collection instrument, the identification of personal assumptions and biases should be identified. The investigator's views on the accessibility and availability of legal information have been influenced by her experiences. The researcher is currently employed in a law library, and a large part of her job consists of enabling access to legal resources, especially case law and commentary, for the library's clients. The researcher works in a closed library, and thus does not deal with members of the public or with lay litigants. The researcher has also studied law and is familiar with both legal terminology and legal resources. The researcher contends that this familiarity with both legal information and law libraries enhances her awareness of many of the issues surrounding lay litigants' struggles to access legal information, and assisted her in working and communicating effectively with the informants in the study.

\section{Literature review}

Recent studies confirm that the number of individuals undertaking their own legal proceedings in overseas jurisdictions is growing. Reports such as the Alberta Rules of Court project (2005), the Litigants in person: unrepresented litigants in first instance proceedings (2005), and the Californian Model self-help pilot program: a report to the legislature (2005) all point to this rise. This increase has been observed particularly in proceedings involving family law, tenancy, employment and traffic offences. The reasons generally cited for this rise are the increase in cases being argued in court, the inability to pay for legal representation and difficulty in obtaining legal aid. The New Zealand Law Commission's (NZLC) report Delivering justice for all: a vision for New Zealand's courts and tribunals makes reference to this 
situation $(2004,25)$. It notes that very little empirical research has been conducted on the situation of lay litigants in New Zealand and that there is no certainty as to whether the numbers of lay litigants are increasing here. The Law Commission does however consider that it is likely that the situation in New Zealand is analogous to that in other comparable jurisdictions, such as Australia, Canada and the United Kingdom. The small amount that has been published locally either concerns the use of Mackenzie Friends (the right of a lay litigant to have a support person present with them in court), or else discuss the issue from a practitioner perspective. Articles by Boshier (2000) and Elias (2000) make brief reference to the increase of lay litigants in the justice system, but without any evidence to support this claim. Anecdotal evidence tends to agree with this. However no examination of the impact, the needs or the numbers of lay litigants in the New Zealand justice system has been undertaken.

The rise in lay litigation comes at a time when many common law jurisdictions are looking at issues surrounding access to justice more generally. Concerns have been raised about both access to legal advice and to the courts, difficulties caused by technical and archaic language, and access to information about the legal system. Much of this literature has been produced overseas, reflecting the fact that other countries have focused a greater degree of attention on lay litigation than New Zealand. This is especially true of the larger common law jurisdictions. In Australia, various reports have been written, such as the Family Law Council's Litigants in person: a report to the AttorneyGeneral (2000) and the AIJA's Report of the forum on self-represented litigants (2005), and Litigants in person management plans: issues for courts and tribunals (AIJA 2001). These reports cover a wide variety of concerns, and have been produced more to raise awareness of the issues, rather than to supply answers. All of them mention the unmet information needs of lay litigants, including: the inability to access relevant materials, the inability to gain 
access to law libraries or the courts, and the intellectual barriers caused by legal terminology. These reports also highlight the need for further research to be conducted into lay litigation and access to legal information and the courts.

Similarly, in the United Kingdom reports such as Lord Woolf's Access to justice: final report to the Lord Chancellor on the civil justice system in England and Wales (1996), and also his interim report on this situation (1995) have been produced in response to a growing awareness of the problems faced by lay litigants, as well as other users of legal information. These reports, like the Australian ones, are of an introductory nature, and identify problems faced by lay litigants, as well as those experienced by the courts and practitioners.

Many of the articles from Canada and the United States tend to follow a similar pattern. However, the approaches taken here have tended to be on a localised level, with each writer concentrating on a particular state, province or county to seek further understanding of the issues surrounding lay litigation in their locality. The articles that have been written have either taken the form of case studies or a description of the approach taken in a particular area or institution (Arbuckle 2005, Bonge 1999, Cameron and Kelly 2002, Fitz-Gerald 2003).

The literature highlights that further research is still needed in order to identify the numbers of lay litigants in the legal system, the reasons people decide to represent themselves and the access lay litigants have to information resources and the courts.

\section{i. Electronic publishing}

Due to the development of internet capability and electronic publishing in recent years, there is a growing expectation that all kinds of information can be, or should be, accessible from a computer. Coupled with this is the relative scarcity of law libraries in many areas, which has increased calls for enabling access in electronic format. 
The literature from Canada and Australia place a lot of emphasis on enabling access to (mostly) primary legal materials via the internet. Much of the Canadian writing comes prior to the establishment of the Canadian Legal Information Institute (CanLII) in 2000 (Scassa 2000, McMahon 1999). Since then the focus has shifted to ensuring that a greater depth and range of materials is available to be accessed (such as provincial statutes and cases, secondary materials or commentary, and for date ranges to be extended) and that materials appearing online are official where possible. The Australian founders of AustLII (Greenleaf et al) have all written extensively in this area, arguing for the importance and benefits of providing electronic access, particularly to primary materials. These benefits include the ease and speed of access that online information allows, enabling access to a broader base of users, timeliness in both accessibility and currency, and a more informed populace. The emphasis has been on primary materials which are produced by the government because issues such as copyright, ownership and whether a fee must be paid for the information are more easily resolved than with secondary materials, which are usually produced by commercial publishers.

There is less emphasis in the literature concerning online publication in the United States, partly because there is quite a wide variety of information is already available electronically on freely accessible databases such as FindLaw (http://www.findlaw.com/) and the Legal Information Institute (http://www.law.cornell.edu/). One reason for this is that, unlike Australia, Canada and the United Kingdom, no copyright is held in government publications (although there have recently been discussions over whether this applies to information produced by state governments as well as federally produced information). Other reasons include the size of the national market place, that most counties have their own public law library, and that university and college libraries must be open for public use if they are to receive free government deposit (which includes legal resources such as legislation). 
Bonge (1999) assessed, by counting the number of law libraries in her local library directory, how likely it was that the average citizen in Michigan could access legal information from their local law library. She went on to enumerate the libraries which hold legal information that the public could access in her state (over 20). This is (discounting private law firm libraries, which generally have quite small collections and are closed) larger than the number of specialist law libraries in New Zealand. She also lists other initiatives that are being undertaken, such as projects run between law libraries and public libraries to enhance access to legal materials and to enable non-specialist librarians to cope more easily with legal reference questions. Westwood (1998) examined what "meaningful access" for prison inmates entails in the light of recent judicial decisions, such as the need for institutions to take positive action to ensure access and resources.

This is not to say that access to legal information in the United States is ideal. The literature still identifies problems and concerns regarding both the level of access and what can be readily and freely accessed, especially for users such as lay litigants (Goldschimdt 2002, Swank 2005, Tones 2005).

Another issue that arises in this area is the distinction between online information that is publicly available, and commercially produced products (usually with some kind of 'added value' such as commentary and links from statutes to case law that interprets it). Commentators such as Treadwell (2000) consider that having the information available via these proprietary databases (in New Zealand the main two are Brookers and LexisNexisNZ, with $\mathrm{CCH}$ primarily producing resources in areas such as taxation and employment law) is sufficient. However, when there is no ability for individuals to access these services, unless they are prepared to pay for them, it cannot really be said that 
access has been enabled in any meaningful sense. These databases are expensive, and not freely available through any public library that the researcher is aware of.

Overall there has not been a great deal of focus on lay litigants in the literature, and in particular their ability to access legal information. This is especially so in regards to lay litigants' ability to access legal information from libraries. The literature that does examine this area has all been written by North American academic law librarians and tends to be focused upon their particular institution and local situation. The authors look at why they should enable lay litigants (Fitz-Gerald 2003), or highlight the problems they face in assisting lay litigants, especially in regards to providing access to electronic resources (Arbuckle 2005, Sims 2004). Literature that looks at the public's access to legal information or to government information more generally can shed some light. However, it is often centred around issues of open access to information held or produced by government, which often require requests made under the Official Information Act 1982 to gain access. The other area traversed in the literature is on the availability of government-produced information online. (Hernon 1994).

\section{ii. Public access to legal and governmental information}

Other commentators have looked at access to legal information more generally, or looked more broadly at access to government information, often via a survey or study that tries to determine what level of access the public has to these resources. Many of the articles that make a case for wider free public access to the law are really arguing for greater online access to such information. With the rise in electronic publishing, expectations of what should be freely and easily accessible online have risen, which has also focused the literature upon this area. 
It is sometimes assumed that there is little interest or desire shown by the general public in accessing legal, or indeed governmental information. Hernon and Chalmers examined the availability and use made of New Zealand government information held in depository libraries. They found that such resources were heavily used in all depository libraries, with most libraries reporting some usage every day. Statutes and regulations were mentioned as resources likely to be made use of on a daily basis. Legal needs were high amongst the reasons cited for use of the materials. The researchers also asked libraries what was not supplied under the depository scheme, but was commonly requested by patrons. Case law was specifically mentioned as one resource that was often sought but unavailable $(1996,8)$. Increases in submissions made to select committees by the general public, protests and concern expressed over proposed legislative change, and wide spread public interest in many recent court cases would also seem to indicate that interest in this area is strong.

There has been a marked shift in the availability and accessibility of government produced and held information in the past ten to fifteen years. It was often necessary to make Official Information Act requests to gain access, and as also noted by Hernon, one needed to be both patient and conversant with legal and governmental processes to have any chance of gaining access to the information required $(1996,25)$. Other factors that impacted on the levels of access included the strong user-pays culture of the late 1980's and 1990's in New Zealand, the lack of availability of court judgments, and the sale of the Government Printer, which deprived the country of a central governmental source for published material. Of these problems, the poor availability of judgments is still a cause for concern. As the submission from the New Zealand Law Librarians' Group (as it then was), noted, if professionals such as law librarians have difficulty gaining access to such material, what hope is there for the average citizen being able to satisfy their legal information needs? $(1994,2)$. 
The development of the Policy Framework on Government-Held Information in the mid 1990's and its subsequent uptake by government agencies has changed this situation significantly. The policy covers principles of availability, coverage, pricing, ownership, stewardship, collection, copyright, preservation, quality, integrity and privacy (State Services Commission 1997). Especially relevant for legal information are the principles concerning availability, coverage, preservation and integrity. The growth in the use and capabilities of e-publication and the government's adoption of an e-strategy have also led to positive changes in this area. The stated objectives of the e-strategy include New Zealand becomes a world leader in E-government through enabling ready access to government information, services and processes via the internet, and that public participation in government is increased. The e-strategy also highlights the need for government agencies to work together, to share resources and integrate services where possible (State Services Commission 2003). All these changes can be seen as positive steps towards the provision of information to the public and which should make the task of lay litigants easier.

There have been other influences that have had a positive impact on the availability of government information, including the shift away from the user pays culture towards an acceptance of the responsibility of the state to provide information to its citizens. There is also a growing awareness of the need for government-wide policies on information and how it can be accessed.

A lot of information is now available electronically, which is in line with the stated goals of the government's e-strategy. Forms for passports or tax returns can be downloaded, and often even filled out outline; annual reports and media releases can all be found on websites. However, one of the biggest weaknesses still apparent is the lack of any substantial access to legal resources. Problems include the inability to access case law, 
and the continuing delays to the PAL project, which have meant that official legislation is still not available online.

\section{iii. Electronic Access}

An important point noted in the PriceWaterhouseCooper report is that it is not just the availability of the internet that makes it such a valuable tool in enabling access, "it is the speed of acceptance as a valid means of providing universal, authoritative, timely, and inexpensive access to all kinds of government information" (1998, 25). Harvey (2002) contends that we have undergone a paradigm shift from print publishing to electronic publishing, and that this has altered expectations surrounding accessibility to information as well as timeliness. He also maintains that the public's desire for knowledge has been both increased and enabled by the rapid growth of the internet.

Declaring that a legal right to accessible law exists both under the rule of law and in human rights law, Kohl also asserts that there is an obligation on governments to go beyond formal publication of the law. Changing technologies have transformed (and continue to transform) the obligations for providing access. The standard, she maintains, should be what a "reasonable person" could find $(2005,29)$.

The ease with which overseas legislation, judgments and the like can be accessed (especially compared to the difficulties that are faced in New Zealand) is another factor that has raised expectations of accessibility and availability. The Price Waterhouse Cooper report on public access to legislation mentions this as one factor that causes many online searchers frustration and annoyance (1999, 32). Other governmental materials, resources and information - such as annual reports, income tax return forms, passport applications and departmental reports - are now available online in New Zealand. Further, the online version of some of these resources is often becoming either the de facto, or in some cases the only version of the resource available. This makes the 
omission of legal resources that much more evident. The online version of some of these resources is often becoming either the de facto, or in some cases the only, version of the resource available.

The impetus for freely accessible online publishing has come in many cases from the Legal Information Institutes (LIIs), first established at Cornell University. The full potential of this type of site was realised by the team from The University of New South Wales and the University of Technology, Sydney, who created the Australasian Legal Information Institute (AustLII). AustLII is generally regarded as the standard for LII's. Its databases include comprehensive collections of legislation, and case law from most Australian jurisdictions, law commission reports, special subject databases on such topics as native title or human rights, a growing collection of both journals and journal articles, law commission reports and much more. The breadth and time frame covered by the collections is also constantly being expanded, as well as continued work being done on more technical aspects of the resource, such as search functionality and file formats.

WorldLII now hosts 545 databases (as of 07/02/2006: http://www.worldlii.org/), including country specific and topical collections, providing varying levels of access to legislation, case law and secondary legal materials from different jurisdictions. The sites they have developed are freely accessible from the internet. Interestingly, those countries with the best developed LII's, such as Australia and the United States, also seem to have the best access to electronic government resources. Greenleaf has suggested that the establishment of AustLII probably encouraged the Australian federal government to move to digital production of its materials. The AustLII team was also able to provide technical advice to the government. With the recent establishment of the New Zealand Legal Information Institute (NZLII) it is to be hoped that this will have a similar effect in New Zealand. 
Commentators in this area have expounded important principles regarding public access to the law. The Montreal declaration on public access to the law (www.worldlii.org.declaration) declares that public legal information is the common heritage of all humanity, and that as such it should be freely accessible and freely available. This is one of the primary motivators behind the constant expansion of the LII databases. Martin and Foster state that a central element of the law is communication, and that therefore it achieves its intended effect only by reaching an audience $(2000,2)$. Other important principles and developments that have been argued for (sometimes successfully) include the use of media and vendor-neutral citations (which allow for the easy identification of a case irrespective of the format or product it has been published in), free access to information rather than a user-pays system, and the importance of basic search functionality on online sites. Writers in this area such as Greenleaf, Mowbray and King (1997), McMahon (1998) and Poulin (2003) have also detailed the advantages of providing (especially) primary legal information in an electronic format such as the ability for almost simultaneous updating, whilst retaining the ability to provide historical sections of Acts in an easy to follow and uncluttered way; the potential for multiple users to access the information at the same time, regardless of location or time; the ability to hyperlink to relevant cross references such as other Acts, regulations, or cases; and the ability to search across multiple publication types, such as both Acts and case law. They also discuss the desirability of such resources being official or authentic, in other words, as being able to be relied upon as true statements of the law and thus for use in court proceedings. The Attorney-General's Department of the Australian Government has just released a proposal for authorised electronic versions of

Commonwealth

Acts (http://www.ag.gov.au/agd/WWW/agdHome.nsf/Page/Publications 2005 Authorised electronic Acts - consultation paper). In essence, it is proposed that the electronic 
versions of Acts published on the government's ComLaw database (http://www.comlaw.gov.au/) be given official status, alongside the print copies.

With the increasing amount of legal information available online in other jurisdictions, attention in the literature is turning to improving the quality, status, and the variety of legal information freely available on the internet. McMahon argues that "electronic publishing provides an entirely different quality of access to the law that cannot be measured simply by calculating the number of people who have access to the laws via a computer" $(1999,14)$. Harvey $(2002,51)$ agrees, pointing out that posting information on a web page is not going far enough in the provision of such information by government. Some kind of facilitation, such as ensuring a reasonable level of internet access at public libraries, the affordable pricing of internet connections, and at least basic search functionality is also necessary. The current state of internet access and capability in New Zealand has been the topic of some recent debate and concern, particularly as regards broadband access to the internet. The recent decision by the government to unbundle the local loop, making the infrastructure for broadband available to other telecommunications providers may be a positive step forward.

\section{iv. Print Resources}

Scassa writes that until courts and governments are willing to supply authoritative versions of primary legal materials "no free, publicly accessible online site is likely to be able to come close to replicating a library as a point of access for legal materials. This is unfortunate as, unlike law libraries, internet connections are becoming widely available and have the potential to be a very far reaching tool for public access to legal information." $(2000,313)$. This is especially true in New Zealand, where there are a very small number of law libraries, and even fewer publicly accessible ones. 
VICTORIA UNIVERSITY OF WELLINGTON

Te Whare Wãnanga o te Üpoko o te Ika a Mäui

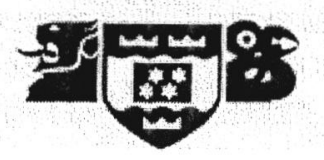

School of Information Management

\section{Statement of Availability INFO 580 Research Project}

Copies of Master of Library \& Information Studies research projects are retained in the School's research project collection, which is managed by the University Library. The author grants to the School of Information Management the right to list bibliographic details and abstracts of the projects in publicly available databases. Papers submitted in electronic form may be made available by the school on a network server. The author retains all rights to publish and/or sell the research paper by any means at any time.

The author states that the project does not violate any copyright or rights of others.

Student (Author): Angela Blake

Supervisor: Alastair Smith

Project Title: Lay litigants' access to legal information in libraries

Year Project completed: 2006

I agree to the above conditions

Signed:

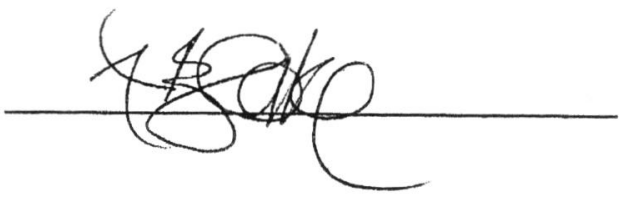

Date:

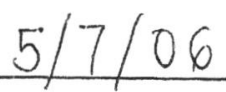


almost exclusive focus on the possibilities and potentialities of electronic resources in the literature, at the expense of more traditional resources.

Another issue that is often raised in the literature are the problems caused by copyright being held in legal materials, such as statutes and case law. This can affect the ability of these items to be reproduced in other formats or within other texts. This situation does not apply in New Zealand. Since the 2000 Amendment to the Copyright Act 1994, there has been no copyright held in legislative materials, judicial decisions and reports of inquiries (s27(1) Copyright Act 1994). There is also legislative provision made for copying for judicial proceedings (s59 Copyright Act 1994).

\section{v. Legislation}

One area that has raised a lot of discussion in New Zealand as regards access to the law is the government's PAL (Public Access to Legislation) project. The stated intents of the project are to make legislation and legislative materials available as quickly as possible after enactment from a database owned and maintained by the Crown at no cost to the public (Lawn 2004, 3).

As the Price Waterhouse Cooper report (1998) acknowledges, the current situation for anyone involved in any kind of legislative research is messy, and may even leave those who deal with legislation on a daily basis confused. Print copies of the statutes and regulations are currently available in law libraries and most public libraries. How up to date they are is another matter again. Currently annotations are done twice yearly, and are not only an expensive but also a relatively fragile way to update legislation. This situation has been exacerbated by the delays in the PAL project. This has in turn led to other problems surrounding the publishing of statutes, and with annotation and compilation making finding up-to-date, authoritative legislation difficult, and requiring many short 
term fixes. Currently, the only bound volumes, which are produced in New Zealand, are Brookers' Statutes and Regulations. These volumes are annotated regularly, and ordered by year. Unfortunately, they have no official standing. The official versions of legislation are now printed in pamphlet form, and are not annotated. This situation means that users may have to check at least two sources to be sure they have the most up-to-date version of the legislation, and that libraries will need to purchase multiple sets of legislation to ensure that they are up-to-date. The situation is in some ways reminiscent of that in Tasmania before they introduced online legislation, and can be seen as a step back for New Zealand.

The PriceWaterhouseCooper report identifies seven factors that are driving the need for change in access to legislation. These are:

- increasing volume of legislation

- growing complexity of legislation

- more dynamic legislation

- maximising Parliamentary Counsel Office efficiency by using technology

- growing openness of government

- broader base of users of legislation

- widespread availability and use of new technology

One of the most important of these factors from a lay litigants' point of view is the increasing volume and complexity of legislation. More legislation is being passed, and at a greater rate than it is being repealed. Moreover, there are more complex links between different pieces of legislation than previously. The New Zealand Bill of Rights Act 1990, which must be considered under many other Acts, is probably the most obvious example 
of this. Another is the Resource Management Act 1991. Legislation is also becoming more dynamic, with amendment acts and regulations being passed far more frequently and sooner after the original enactment than previously. There is also a broader base of users of legislation nowdays, with the growing volume of legislation and the more complex nature of our society meaning more and more people are affected by legislative provisions. The report notes that "the submissions revealed a much wider range of interest in public access to legislation than many were previously aware of' $(1998,23)$.

\section{vi. Case law}

Interestingly, whilst access to case law in overseas jurisdictions such as Canada and Australia receives a similar amount of attention in the literature as do issues surrounding access to legislation (Greenleaf, Mowbray and King 1997, Scassa 2000), this is not the case in New Zealand. In common law jurisdictions, access to case law is an important aspect of access to the law more generally: "the provision of online legislation without a corresponding access to the decisions that interpret it results in a very partial form of access to primary legal materials" (Scassa 2000, 305). There are two reasons that access to case law is so important - it enables the user to see how the courts have interpreted legislation, and it gives expression to the rights enjoyed under the common law. Unreported judicial decisions are cited very frequently in New Zealand courts, and these can be amongst the very hardest of legal resources to obtain, especially for lay litigants. It is difficult, indeed sometimes impossible for professionals to gain access to unreported judgments. The PAL report, (whilst stressing that its focus is on access to legislation) also highlights the need for any improvements made in access to legislation to be complemented by improving access to other legal materials $(1998,33)$. 
As may be expected, what little has been published on access to case law in New Zealand has come from a practitioners' perspective. Authors such as Harvey (2000, 2002), Lake (2004) and McKechnie $(2000,2003)$ have all discussed the creation of an online database of court decisions for the judiciary. This database has since been established, and is a big step forwards. Previously, judgments were produced on paper - or in the case of District Court judgments, often not recorded at all. At the current time there would appear to be minimal interest in facilitating wider access to this database. Harvey and Lake both mention the possibilities of making this collection publicly available some time in the future, but it is clear that this is not considered a priority. This leaves most participants in the court system requiring access to proprietary products such as comprehensive case law databases or report series in order to get hold of the information they require. This often leads, in practical terms, to reduced access for lay litigants, as they generally cannot afford to pay for these resources.

The subscriptions to legal proprietary databases are generally far beyond the reach of most individuals, and even many libraries, to afford. Bonge notes the difficulties public libraries face in attempting to provide anything like comprehensive access to legal information, especially with regards to the expense of both acquiring and maintaining legal resources, as well as the training that is often necessary to deal with these products $(1999,2)$. Yet it is usually the case that these databases are the only place that unreported cases can be easily accessed from - with the possible exception of the three larger law society libraries in Auckland, Wellington and Christchurch.

\section{vii. Conclusion}

There are many gaps apparent in lay litigants' ability to access the law, and at least as many gaps in our knowledge of the issues faced by lay litigants in New Zealand. There is 
currently no information as regards how many lay litigants are in our legal system, where they are searching for legal information and what information is available and accessible to them.

Whilst the literature discusses access to primary materials in detail, secondary resources, or commentary as they are also known, are hardly referred to at all. Yet resources such as journals, looseleaf texts and books that analyse areas of the law, and the judicial interpretations of these areas, can be amongst the most accessible of the legal information resources to laypeople.

There has been very little examination made in New Zealand as to the extent that the public can access legal information, and what problems they do face in trying to gain access. The National Library's report on the use of depository libraries would suggest that legal information is widely sought after, and used, and that enabling greater and easier access would be in the public advantage. It would seem likely that litigants do encounter problems accessing the materials that they need (articles by writers such as Kirby (2000) and McKechnie (2003) highlight the difficulties professionals face at times) but there is no empirical evidence to base this assumption on. There are enough differences between the situation here and overseas to warrant research being undertaken locally. The government has just announced that they are undertaking a nationwide survey to determine the "extent and impact of unmet legal needs". The survey will attempt to identify barriers to legal information and to establish the numbers of people who cannot afford a lawyer or cannot access services. It will also ask questions about the types of legal problems people have had, if they used legal services and if so, which services they used. The survey is to be conducted by the Legal Services Agency (Burton 2006). 
This research builds upon the work and studies that have been produced on lay litigants and lay litigation overseas. Specifically, it examines what access lay litigants do currently have to legal information in New Zealand. This is a current deficiency in the literature. It also tackles the issue from the point of view of libraries, which may be viewed as information intermediaries. In this way, the perspective of information providers, who interact often on a daily basis with the users of this information, can be obtained.

\section{Methodology}

Interviews were conducted with librarians from the district law society library, university law library, national library and a central public library in a large urban area. A cross section of library types was selected to examine what levels of resources and materials were available in each library, as well as any differences in levels of access enabled. The interview sample was limited to one example of each library type for reasons of convenience and due to time constraints.

The study requires the interviewer to have an understanding of the New Zealand legal system, law libraries, legal materials and information, as well as experience in using these resources. The researcher has this knowledge and experience.

\section{Population}

It was decided at an early stage to interview librarians rather than lay litigants. This decision was made for a number of reasons. Firstly, because the research was to be focused on information available from libraries, this was one way of maintaining that focus. Secondly, making contact with librarians was felt to be more achievable in the time available than recruiting a pool of lay litigants who would be willing to talk about their 
experiences accessing information. Finally, time constraints meant that gathering information from a discrete and fixed pool of informants was likely to be more productive and give a better information set to work from.

Five librarians were interviewed. The original research plan was to interview six librarians from three different types of libraries in two cities, but time constraints meant this number had to be reduced, as well as narrowing the focus to just one city. However, one other library was able to be added, with the final result that five librarians from four libraries were interviewed. Therefore a variety of libraries and respondents could still be covered. Informal discussions were held with other librarians and with lawyers both before and during the research process, which greatly aided the information gathering and data analysis processes.

The librarians interviewed all deal with, or had dealt with reference inquiries and with lay litigants as part of their jobs. They were approached because of their subject knowledge, and because of their familiarity with lay litigants' needs and concerns, as well as the types of problems they are likely to present; or because they are generally the member of staff who deals with these types of inquiries at their library.

The size of the population was dependant upon the number of willing participants, and also upon time constraints. The population was also constrained by the fact that specialist law librarians do not make up a large group in New Zealand. Those that deal frequently with the public make up an even smaller group. Librarians from four types of libraries that hold legal materials as part of their collection were interviewed. These libraries are either open, or allow restricted access to the public. One was not, but was often assumed by members of the public to be accessible; therefore they also had experience dealing with lay litigants. All those contacted (including those who finally 
could not be interviewed due to time constraints) were incredibly helpful and generous with both their time and their knowledge.

\section{Data collection}

Prior to data collection, ethical approval for the study was obtained from the Informatics Human Ethics Committee at Victoria University of Wellington.

Interviews with selected key informants were chosen as the method of data collection for this study. The information needs of lay litigants, and how they access information have not been examined in New Zealand, thus a need exists to explore the current situation, before more detailed research can be conducted. The sample unit was the library and particular respondents were targeted depending upon the size of the library. In smaller libraries where the library manager tends to do a lot of library work as well as management, managers were approached as it was felt their overall knowledge and experience in this area, as well as their day to day dealings with lay litigants would provide the richest information set. In larger institutions, subject reference librarians were approached, as these individuals were most likely to have encountered lay litigants. As key informants, selected staff were able to give a great deal of information both about how their library deals with lay litigants and about the wider implications and issues surrounding this problem.

The interviews were conducted individually, in person. The advantage of this type of data collection is that information is gathered that would not be using other methods such as indirect observation. This process allows the interviewee to give background and historical information, and to place their responses in a wider context. It also gives the interviewer a degree of control as to what information is received. Disadvantages include that the information received can be indirect, in the sense that it has been filtered 
through the views and biases of the interviewee. Depending on the information sought, it may also be second hand. Care was taken to not ask questions that would have librarians making assumptions about their patrons and their needs. An unstructured format was used in the interviews, although the researcher was following a guide. This way the researcher could ensure that enough data was collected to answer the research questions, while also allowing respondents to give additional comments, which were rich in information content. Participants were encouraged to contribute information beyond these parameters. In this way additional, content-rich information was gathered, which was often very useful as case studies are designed to uncover patterns of behaviour and attempt to provide some kind of explanation for this behaviour. During the interview process new questions arose, and where possible earlier participants were contacted for their input on these points.

The interviews were recorded, and later transcribed so that the researcher was not distracted by having to take notes and so that the interview was not disjointed.

The interview guide consisted of seventeen questions that covered the following areas:

- The size of the library's legal collection

- Number of staff who deal with legal information inquiries

- Frequency of legal information queries

- What kind of legal information queries they receive

- Whether the library can assist with the queries received

- Where else they recommend people go to access information

\section{Method of data analysis}


This study has relied upon information gathered from interviews with librarians. Other background information was gathered from an extensive literature review. Useful information and advice was gained from informal conversations with law librarians, lawyers and other interested parties.

Each interview was numbered and transcribed. Manual coding of the data was used, as opposed to using computer software, due to the short time the researcher had to familiarise herself with the software, particularly the more sophisticated features of it that would offer more functionality. Any identifying information was edited out to ensure the confidentiality of the respondents.

Reading the transcripts and picking out the main features or themes of the data identified initial data categories. These categories were then sub-divided as the researcher identified new sub-categories. This process then reduced the data to a manageable number of themes.

Whilst responses to each question from the set of interview questions was treated and analysed individually, more attention was paid to certain key questions. Information was analysed to uncover any recurring themes or processes in the way that lay litigants were handled, and what issues recurred. The sum of responses was also analysed to try to establish a picture of the current situation for lay litigants who used libraries to try to access information.

Not all of the interview questions are explicitly addressed in the discussion. Some were used as more of a guide to the topic of the project, whilst others helped to build a picture of the current situation or establish the environment that the research was being conducted in, such as the size of each library's holdings, and their main user groups.

Because qualitative research is descriptive - interested in the meaning and understanding gained from the research process, and because that process is inductive - that is, concepts, theories and hypotheses are derived from details - much of the data analysis 
was done simultaneously with the data collection and the writing up of the findings. Due to this simultaneous process, each step informed the other to some extent.

\section{Ability to replicate study}

This study should be relatively easy to replicate in another setting. This would be useful to see if a similar picture of the current situation of lay litigants is established. Because the researcher has explicitly mentioned any biases and assumptions she held, these can be taken into account when repeating the study. The researcher has also outlined her methodology, the guiding research questions and the focus of her interview questions.

\section{Discussion}

Librarians from four types of library were interviewed: a district law society library, a university law library, a public library and the National Library of New Zealand. They shall be referred to throughout the following discussion by their library type.

The libraries approached for interviews were selected for a number of reasons. The law libraries were chosen as they were either to some degree open to the public, or because it was likely that the public would assume that this was the case and would contact these libraries for assistance. The librarians at these institutions are also not only experienced and knowledgeable in their subject field, but also have experience in dealing with reference inquiries and lay litigants. The public libraries were chosen precisely because they are public, and likely to either be approached by lay litigants, or that lay litigants would be sent on there from other institutions. 


\section{Legal holdings}

The number of legal holdings in each type of library is reasonably similar. The law libraries hold about 110, 000 - 115, 000 volumes in their collections. Public libraries have less naturally, but still have good legal collections, both holding somewhere around 25,000 - 30,000 volumes. All libraries carry official government publications such as New Zealand statutes and regulations, the New Zealand parliamentary debates, the New Zealand Gazette and the Appendices to the Journals of the House of Representatives. All libraries also hold at least some case law. The public library has only the New Zealand Law Reports. The National Library carries all New Zealand law report series. Only the law libraries hold overseas law report series and unreported judgments. Both law libraries have considerable collections of unreported case law. The district law society library carries these judgments as part of its mission. The university law library was in the fortunate position of having been gifted a comprehensive collection of unreported judgments some years ago. They have also taken over the supply of judgments that are indexed in The Capital Letter, a weekly publication that summarises judgments of note and also comments on other legal and governmental issues.

The other real difference in the various libraries' holdings is in the electronic resources available. The only library that to some degree makes these resources available is the public library. Databases such as Brookers and LexisNexisNZ are not freely available through the library's website or in-house, but can be accessed through a mediated search via their research service. This service will undertake searches on various subscription databases for a fee. Freely accessible websites, such as the Knowledge Basket's legislation and Hansard pages, the unofficial interim legislation site (www.legislation.govt.nz) and Waitangi Tribunal reports are linked to from the law subject page. This page also gives 
instructions on using resources such as the New Zealand Parliamentary Debates and statutes.

The major reasons cited for not making legal databases available from the public libraries is the cost of subscriptions, and also the difficultly of taking out a subscription. The legal publishers in New Zealand tend to price their database subscriptions depending upon how many users will have access to the product. This is quite impossible for public libraries to state. Another reason for not subscribing, or making the databases freely available is the price of the products relative to the current use made of legal resources in the libraries. There does not seem to currently be enough demand to warrant the expense. Whether online access to this information would result in an increase in usage is difficult to say, but given the expectations of so many people today that if information cannot be found online, then it is not available, it is certainly a possibility. Whether access to these databases would actually increase lay litigants access to useful information or make it easier for them to find relevant information, is also questionable.

Another issue is the limited space and amount of computers that most libraries have. The best lay litigants can do is to get mediated searches performed (for a fee) by research services like the one provided by the public library. Therefore, there is no library from which lay litigants can access these databases for themselves. Whilst some of the information held in these databases is also produced in hard copy, there are a growing number of items and resources on these databases that are not produced in another format. Most of the libraries contacted are moving towards holding more of their collection electronically. This is especially true of the law libraries. Resources such as law reports, legislation and looseleaf texts lend themselves well to electronic production, and this format also circumvents issues such as journal or law report parts being lost or use being limited to one user at a time. It is unclear at this stage what difference electronic 
legal deposit will make to this situation. Legal deposit is being extended to cover electronic documents from August 12th 2006. This will not be retrospective. In essence, publishers are required to deposit electronic materials as well as print documents. If the material is published with restrictions (such as requiring a subscription for access) then the National Library will only make it available to up to three people at a time (National Library of New Zealand 2006). This precludes any ability to make this information available over the internet and thus it is likely that access to the legal databases will be limited to in-house use at National Library, as well as being subject to the number-ofusers limitation. Therefore at best it will only aid users in Wellington who can go into the National Library to use these resources.

One librarian did not think greater access to legal information online would necessarily improve access for lay litigants. "It's going to give them more information but it's not going to give them the information they need to actually do anything." This librarian had similar concerns about the provision of case law by the government, when this eventually happens. Because legal reasoning is often very different from the way people approach problems and issues in their day-to-day lives, it is not always easy for the lay person to understand the information contained in these documents, or the reasoning behind the decisions. Many judgments that are reported are appeal cases that are concerned with the procedure of the law, or the interpretation of the law rather than the factual events of the case. Often decisions come down to very fine points of law. All librarians interviewed for this project agreed that they still experienced difficulties at times trying to find information that would answer their legal questions. All those interviewed were librarians in senior reference and research roles who had often quite considerable experience dealing with legal information. 


\section{Staff numbers coming into contact with lay litigants}

The law libraries have a small staff of about five to six fulltime equivalents, and possibly all librarians (as opposed to library assistants or shelvers) may deal with lay litigants when they contact the library, either in person or by telephone. In one library it is most likely to be the manager who deals with these inquiries, in the other law library the reference staff generally deals with lay litigants. In the public library and the National Library reference staff deal with inquiries from lay litigants. Both have reference teams of a very similar size, about 6 full time equivalent staff. In all cases qualified librarians, usually with reasonable subject knowledge, deal with these inquiries, whether any assistance was given or not. The situation is fairly similar in public libraries. Reference teams, which would generally deal with these types of enquiries, were also reasonably small, usually less than ten fulltime equivalents. Again, the majority of staff who deal with these inquiries are qualified.

\section{Policies regarding access to legal information}

Although no law library had a formal, written policy concerning access, those libraries that are not open, or which do not make their full collection available to the public do have unwritten policies concerning lay litigants' access to their holdings. These policies may be as simple as that they do not assist lay litigants. The university law library's policy is that the public may use resources available on the open shelves for one week every six months. Electronic resources and items held on closed reserve are not made available to the public (except for the Laws of New Zealand, which is held in closed reserve, but made available). This is due to policies in place concerning access by lay litigants and/or the public, and also because closed reserve items are high demand items and thus likely 
to be needed by main user group. If access is allowed to these items, it is usually under staff supervision, and for a relatively short period of time - generally long enough to check or copy a required section. Time spent with a reference librarian is also kept to a minimum. The law society library does not allow members of the public to use their library. As it is funded completely by lawyers, for lawyers there is a rule in place barring public access. These libraries will rather refer lay litigants on to other institutions such as the Citizen's Advice Bureaux, the Community Law Centre, the National Library (which holds all New Zealand published legal materials in accordance with legal deposit) or their public library. These policies have arisen from issues surrounding funding and the primary user groups of the law libraries. Because these libraries are not funded, or fully funded by public monies, and because the libraries have been established with a particular and defined user group in mind, it is hard for them to justify expending time and resources on others who fall outside their core user group. However, in practice lay litigants are on occasion given assistance. This may be for reasons of expediency or because the library approached is the only holding library of a certain resource. One librarian commented that if they could assist someone quickly by recommending a particular resource, or if they knew that the resource they were after was not easily accessed elsewhere in the area, they would make it available. The university law library will often give lay litigants more assistance if they come in during a quiet period, such as during exam time or the holiday period. Other reasons that these libraries may on occasion assist lay litigants include whether the librarians have time to assist them, if the query can be answered quickly and easily, or if the request is for a discrete item. These libraries will also interloan items when requests are sent from another library (subject to normal interloan conditions. For example, usually libraries will not interloan items such as looseleaf texts, which can be amongst the more useful commentary or secondary resources for lay litigants). 
Depending on the nature of the inquiry, librarians in closed or semi-closed libraries will generally try to recommend lay litigants elsewhere. If they have a problem that could be clarified or explained by using a resource that is held at a publicly accessible library, the general rule is to send them there. All librarians interviewed mentioned that they would recommend litigants to the other publicly or semi-publicly accessible libraries in the area. It is therefore possible that lay litigants can end up going around in circles, being referred on from place to place. This is because no one library is really set up to assist them with their inquiries. If lay litigants have a problem that it is unlikely they can answer from a book, they will often be referred to the Community Law Centre, or advised to seek legal advice. Once the Community Law Centre has been exhausted, there really is nowhere else to send people if they do not wish to retain the services of a lawyer. All librarians stressed that they are very cautious not to step over the line into giving legal advice. They are all quite aware of the issues concerning unauthorised practice of the law and the giving of legal advice.

Publicly accessible libraries do make all their holdings available, subject to any restrictions that are in place for all users of the library's resources - such as not being able to remove reference items from the library.

\section{Types and numbers of inquiries}

\section{i. Types of enquiries}

There is a wide range of legal queries received from the public. These range from inquiries as to what a particular section of an Act covers, to genealogical information (perhaps concerning a relative who was a judge), to quite specific and detailed legal questions on particular issues. Most librarians noticed a difference between more general inquiries from the public at large and those from lay litigants. They also said that they 
could usually tell in the first minute or so of their interaction that they were dealing with a lay litigant. The difference is usually in the kind of information sought. Inquiries from lay litigants tend to be quite specific and involved, concerning particular details and circumstances. Those from the wider public tend to be simpler and of a more general nature.

In general, although there is a certain stereotype of lay litigants that often prevails, the individuals and their needs can be quite diverse. Whilst problems and issues concerning family law, criminal law and traffic law can be recurring themes (in much the same way that a general practitioner will often deal with numerous similar cases), there is still a broad spectrum of concerns that are encompassed by lay litigants. Other legal areas that librarians had assisted lay litigants with (in some way) included land law, Maori land, aviation law and commercial transactions. Some lay litigants that approach the libraries will still be asking quite broad questions, seeking any help they can get. Others, usually more experienced, will know more clearly what they want and may just require access to a single resource. All librarians surveyed had at least one story to tell of a successful lay litigant - someone who had uncovered the necessary information, understood the processes involved and argued their case successfully in court.

Differentiation was drawn by the librarians interviewed between the general public seeking legal information, people with a legal problem and lay litigants. Whilst the researcher was aware of some of the differences, this was a point that came out much more clearly from the interview process. The two former groups' questions are (generally) fairly easily answered, especially now that so much general information is being made more widely available, and in a more digestible form, via such means as the internet and in pamphlets. Legislation (albeit not the official version, and only what is currently in force) is now available online. Many government departments and other 
agencies and organisations such as the New Zealand Law Society publish pamphlets and give basic information on their websites, which can often be enough to answer general queries. Those with legal problems are often seeking some information to start them off, or establish just what exactly their rights and responsibilities are. These problems may be as simple as discovering exactly what offence they have been charged with under the Land Transport Act 1998, or the Crimes Act 1961. Lay litigants are, in the words of one of the interviewees, "actively involved in disputing something". They are also usually in the situation of having been through this process of trying to find general information on their problem, have often tried mediation or other methods to resolve their issue, and are now faced with trying to get quite specific information on a particular point or area of the law. It is the people in these circumstances whose information needs tend to go unmet.

\section{ii. Number of inquiries}

Inquiries from lay litigants were hard for librarians to quantify, mostly due to the irregularity of approach and because no formal records are kept. It can vary widely, with quite a few people approaching a library in one month, and then no approaches for six months. Libraries on average tended to get somewhere between two and five legal reference inquiries a week. These figures vary quite markedly, and there was also quite a lot of variation between the different libraries. The public library seems to deal with substantially more legal enquiries, with approximately ten to twenty legal inquiries a day. The university library receives on average about four to six inquiries from the public a week. This is followed by the National Library, which tends to receive two or three legal reference inquiries per week. The district law society library probably deals least frequently with lay litigants, perhaps one a week, and often less. This is not surprising, given that this is not in any way a public library. Although these numbers are smaller than 
those for many other types of reference inquiries, over the course of a year this still becomes a quite significant figure. Of course, these figures are not quantifiable or able to be validated in any way.

It is also impossible to know if it is the same people approaching different libraries. Lay litigants tend to make one-off visits to particular libraries - although this is not always the case, especially with those who return to use the resources, rather than the librarian's expertise. Repeat visits are usually discouraged in the law libraries.

At least one library has not noticed any increase in the numbers of lay litigants approaching the library. In fact, a decrease in the requests for legislation had been noticed, which may be attributable to the Public Access to Legislation project. The other libraries either thought the situation had stayed quite static, or that the increase noticed was attributable to other factors. The public librarian commented that although staff had assumed changes such as the provision of legislation online would result in a decrease in the requests for such items, this was not the case. This study is unable to point to the reasons why, but possible factors include that the site is not well known, that people prefer to use the hardcopy, especially for browsing through, or that they require help in using these items. The only library that had noticed an increase in the queries received from the public attributed this more to the location of their library, which moved about ten years ago.

Most librarians agreed that lay litigants could usually be spotted; especially 'novice' lay litigants. However, this was not always the case. It would appear to be harder for public or semi- public libraries to ascertain this.

Because lay litigants are not the core clientele of any of the law libraries (or even a peripheral group), and because these libraries are either funded or part-funded by the groups that they have been set up to serve, in general as little time and effort as possible 
is expended upon them. Lay litigants are either recommended to try elsewhere or are assisted briefly and, in the words of one of the respondents "actively discouraged from returning". Whilst all those interviewed had sympathy for the position that many lay litigants find themselves in, they acknowledged that they were generally very limited in what they could do to assist.

The public libraries, whilst more willing and able to assist lay litigants, were clear about drawing a line between assisting them to find information and giving any kind of advice about their situation. They would also recommend that litigants seek legal advice, especially from the Community Law Centre, or at the very least approach the Citizens' Advice Bureau.

\section{iii. Ability to answer inquiries}

A mixture of resources are used to answer inquiries. Often primary resources are used to answer more broad or simple questions from the public such as "what does s138(2) of the Land Transport Act 1998 say" or "what cases did my grandfather appear in?" For the more detailed queries usually received from lay litigants, commentary on the primary sources is more likely to be recommended. One librarian said that unless a case exactly on point could be identified staff would generally point lay litigants towards commentary rather than case law. This is because commentary is more likely to explain the legal situation and the way the legislation has been interpreted by the courts in language that lay litigants can comprehend. Another librarian said that previously their library's policy had been to briefly explain how law reports worked to lay litigants and then leave them to search for relevant case law. This proved to be highly ineffective, with most people coming back empty handed. They now also recommend lay litigants towards commentary where possible. 
All respondents mentioned that it was more a matter of lacking the ability to help than a lack of resources that impeded them in assisting lay litigants. Having the time and having permission to assist were the two problems most commonly mentioned by the law librarians. Whilst lay litigants' enquiries usually could be answered by referring to the resources held in the law libraries, typically they are not answered. This is due to these libraries' policies. Rather, other libraries and information services that are open to the public are recommended to them. On occasion if the librarian can assist quickly they will do so, or if they are the only local holders of an item that is required they do make this available.

The librarians in the public libraries tended to have less experience with legal materials. However, their wider knowledge of, and access to other resources can prove useful, especially when diverse, non-legal resources need to be consulted to assist their patron. Public librarians also expressed less confidence in both being able to use these resources effectively, and in being able to assist others to do so. One reason for this is that there are no specialist subject librarians for law in these libraries, so reference librarians who also deal with other subject areas cover this area. One librarian remarked that although feeling reasonably competent dealing with government publications such as the statute books and New Zealand Parliamentary Debates, other materials like the looseleaf commentary resources or the law reports were less requested and thus the same level of confidence was not felt when assisting patrons with these resources. Because both of these types of resources are not straightforward to deal with, unless one is familiar with them they are difficult to use, let alone assist others with. Another librarian working in a public library referred to the fact that some of the staff were more comfortable and competent with these resources than others. A lot of this was again dependant on how familiar people were with these resources. So although they can show patrons the 
resources and usually give a quick run-down on how to use them, they cannot always answer more intricate questions or help people find the exact information they are after. This is attributable to their lesser experience with these resources, but also due to the nature of legal information resources. Law, like other highly specialised disciplines, has its own vocabulary. There are also resources produced such as the looseleaf text and the law report series, which are fairly unique to this area. These items are not always easily used by the uninitiated. However, this does raise further issues regarding lay litigants ability to access this information. The only library where they are guaranteed consistent access to legal information is the public libraries. If the librarians there - information specialists are not always confident in their ability to assist users with legal information, then this is another factor that lowers the accessibility of such information resources need to be consulted to assist the patron.

Respondents also commented on the lack of suitable published resources for lay litigants, of the type that is produced overseas. There is no resource or set of guides made for the New Zealand market that is comparable to what is available in other jurisdictions such as the United States and Canada. These resources are also becoming more widely available in other comparable jurisdictions like Australia. This type of resource gives information such as what happens during a trial or the preliminary process, what happens after a case has been lodged at the court, or an overview of the current legal situation in a certain area, but at a level above that of the type currently produced (such as pamphlets or short blurbs on websites).

Another problem that was identified by all librarians interviewed is that, as one respondent said: "most people are not aware of what they need to know to be able to successfully navigate their way through the law." The language, structure and format of 
legislation, case reports and so forth are all very precise and particular to the law. These structures can be hard for people not trained in this area to penetrate.

All libraries reported back experiencing some difficulties with lay litigants. However, as one respondent expressed it, the issues were generally no greater or worse than those faced by anyone whose job involves dealing daily with the general public. The only librarian to bring up specific problems was from the public library, and these problems were more concerned with the resources themselves than lay litigants specifically. He mentioned that legal texts were the most likely resource to be stolen from the library. Other problems they sometimes had with their legal resources included pages from looseleaf texts going missing or being misfiled, and annotations being ripped out of the statutory instruments.

\section{Other ways libraries assist lay litigants}

In general there is not much else libraries can do once they have shown inquirers the resources and how to use them. Both the public library and the university law library provide online guides to legal information. The public library's outlines the resources that the library has, and some basic information on using the resources. They also produce a hard copy pathfinder to legal information, which gives basic information on what is held and how to use it. This has proved to be very popular. The university law library also has a web page that gives similar information (although geared more towards law students than the general public), outlining their holdings and giving location guides as well as basic user information.

The libraries do not appear to have any kind of interaction or knowledge of each other's activities in assisting library users with legal information inquiries. During the interview 
process, interviewees often asked what other libraries' policies regarding access for lay litigants are, or exactly what access they allow. Greater interaction between these libraries could help improve the situation for lay litigants. Workshops such as the ones detailed by Bonge $(1999,1132)$ where law librarians instruct public librarians on the use of legal resources may also be useful.

\section{Conclusion}

This study had five main research objectives as described in the Objectives section. They were concerned with the current state of lay litigants access to legal information from libraries, how libraries deal with lay litigants' inquiries and whether any ways of improving lay litigants' access could be identified.

The study has found that lay litigants have a reasonable level of access to most primary print legal resources from libraries. This is especially true of statutory instruments and reported case law. All libraries made these items available, with the only limitation being that the public library only holds the New Zealand Law Reports. It does not hold any other law report series.

The policies that libraries have in regards to lay litigants' access to their collections depend upon the type of library. They enjoy the same access as any other patron of the public libraries, and are subject to the same restrictions, such as not being able to remove reference items from the library. Lay litigants' access to the holdings of the law libraries is more limited. This is because these libraries are not public and have been established to serve a particular user group. Lay litigants may still access the print holdings of the university law library, but not their electronic resources. They have no right of access to 
the law society library. However, both these libraries will on occasion assist lay litigants, especially if they are the only holding library of a required resource.

Lay litigants' access to electronic legal resources is very limited. The proprietary products are only easily available in the law libraries, and lay litigants do not have access to them. They may access any electronic resources that the public libraries make available, but these do not include legal databases. Many enquirers did not seem to be aware of the resources they could freely access online, such as the interim legislation database.

All libraries deal with lay litigants' queries in similar ways. Most libraries will refer lay litigants to secondary resources, such as commentary on the legislation when possible. Only one librarian interviewed will generally take litigants to the primary resources first. The librarians will show resources to users and may instruct them on how to use them,

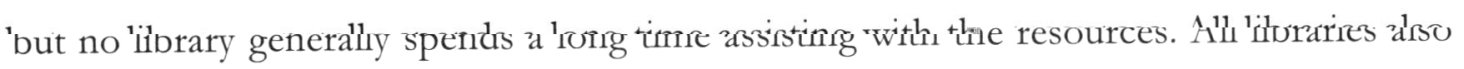
stressed that they will not give advice or even their opinion as regards the lay litigants' legal situation. They were all highly aware of the possibility for crossing over into giving legal advice.

One way that access could be improved for lay litigants may be to begin some dialogue between the libraries that habitually deal with their inquiries. Each library seemed quite unaware of the others, what exactly they hold in their collections and what exactly their policies are regarding access by lay litigants to their collection.

It would appear that it may require policy shifts rather than just improvements in the provision of information to truly enable lay litigants. Whilst the move towards online access is increasing the public's access to legal information, it tends to be information 
that usually requires interpretation and analysis from a lawyer, despite the current shift towards plain English law drafting. Moves towards improving access for lay litigants overseas have included setting up kiosks and small libraries attached to courthouses. These libraries also produced a range of guides to the different subject areas within their collections as well as guides to where else information on certain topics can be accessed. These guides are designed for lay litigants and members of the public rather than someone with a legal education or background. These guides are also often produced in a variety of media, usually in print, online and on video. Information kiosks also usually attached to courthouses or to local citizens' advice centers are another initiative that have generally been set up by local governments. It is often this kind of "in between" resource that is needed - an explanation of the procedures, the rituals and language surrounding the law and the court process.

\section{Recommendations for further research}

- More research is needed to determine the numbers of lay litigants in the legal system. This is necessary to establish whether this group is fairly static, or a growing class who's legal information requirements may need to be met in a more formal and extensive manner. These numbers are not easy to ascertain, but the survey being undertaken by the Legal Services Agency later this year should provide some figures (Burton 2006).

- Research is also needed to establish where else lay litigants are currently receiving legal information from - for example, are they searching online, are they using the Citizens Advice Bureaux or Community Law Centres - and if these sources 
are adequate for lay litigants' needs. Research that establishes exactly what those information needs are could also be undertaken.

- With the passing of the Lawyers and Conveyancers Act 2006 earlier this year, research could also be conducted on the current situation of district law society libraries and whether changes in funding, and thus accessibility, are feasible in this new environment. This could be one way to make more legal information available to lay litigants (and the public at large). 


\section{Bibliography}

Alberta Law Reform Institute. 2005. Alberta Rules of Court project. Edmonton, Alberta. http://www.law.ualberta.ca/alri [accessed 13 December 2005]

Arbuckle, K. 2005. Target: fair and reasonable public access to all legal information improving access to justice. Spring 2005 Canadian Forum on Civil Justice: 10-11

Australian Institute of Judicial Administration and the Federal Court of Australia. (2005). Report of the forum on self-represented litigants, Sydney, 17 September 2004. Melbourne, Australian Institute of Judicial Administration, 2005

Australian Institute of Judicial Administration. Courts and Public Committee. 2001. Litigants in person management plans: issues for courts and tribunals. Carlton, Victoria: Australian Institute of Judicial Administration

Bonge, B. 1999. Access to justice: public access to legal information. 78 Michigan Bar Journal: 1130-1134

Boshier, P. 2000. The Family Court and the future. 4 Butterworths Family Law Journal: 1123

Burton, M. 2006. Improving access to justice focus of legal aid survey.

http://www.beehive.govt.nz/ViewDocument.aspx?DocumentID=26122 [accessed 13 June 2006]

Cameron, C. and E. Kelly. 2002. Litigants in person in civil proceedings. 32 Hong Kong Law Journal: 313-330

Moorhead, R. and M. Sefton. 2005. Litigants in person: unrepresented litigants in first instance proceedings. London: Research Unit, Department of Constitutional Affairs

Elias, S. 2000. Address by the Right Honourable Dame Sian Elias GNZM, Chief Justice of New Zealand. 3 Butterworths Family Law Journal: 107-112

Family Law Council. (Australia). 2000. Litigants in person: a report to the Attorney-General. Barton, A.C.T.: The Council

Fitz-Gerald, K. 2003. Serving pro se patrons: and obligation and an opportunity. 22 Legal Reference Services Quarterly: 41-73

Goldschimdt, J. 2002. The pro se litigant's struggle for access to justice: meeting the challenge of bench and bar resistance. 40 Family Court Reviews: 36-62

Greenleaf, G., A. Mowbray and G. King. 1997. The AustLII papers: new directions in law via the internet. Journal of Information, Law and Technology. www.law.warwick.ac.uk/jilt/leginfo/97 2gree/ [accessed 20 November 2005] 
Greenleaf, G. et al. 2002. The Hong Kong legal information institute (HKLII): its role in free access to global law via the internet. $4^{\text {th }}$ International conference on law via the internet, Montreal October 2-4 ${ }^{\text {th }}, 2002$.

Hannaford-Agor, H. 2002. Access to justice: meeting the needs of self-represented litigants. 1 Civil Action: 1-4

Harvey, D. 2000. A judicial perspective on public access to case law on the internet. [2000] University of Technology of Sydney Law Review 7 http://www.austlii.edu.au/au/journals/UTSLR/2000/7.html [accessed 15 December 2005]

Harvey, D. 2002. Public access to legislative information and judicial decisions in New Zealand: progress and process. 10 Australian Law Librarian: 48-67

Healey, P. 2002. In search of the delicate balance: legal and ethical questions in assisting the pro se patron. 90 Law Library Journal: 129-147

Hernon, P., and A. Chalmers. 1996. Public access to New Zealand government information: the role of the Depository Library Scheme - a research report. Wellington: Research Unit, National Library of New Zealand

Hernon, P. 1996. Government information policy in New Zealand: businesslike but evolving? 13 Government Information Quarterly: 215-230

Judicial Council of California. 2005. Model self-help pilot program: a report to the legislature. California: Centre for Families, Children and the Courts.

Judicial Studies Board. 2004. Fairness in courts and tribunals: a summary of the Equal treatment bench book. London: Judicial Studies Board

Kirby, the Hon. Justice M. 2000. Free the law - beyond the "dark chaos". [2000] University of Technology of Sydney Law Review 2.

http://www.austlii.edu.au/au/journals/UTSLR/2000/2.html [accessed 24 November 2005]

Lake, J. 2004. Public electronic access to New Zealand judicial decisions. New Zealand law librarians' conference 22-24 July 2004. http://www.nzllg.org.nz/Conferences.cfm [accessed 20 December 2005]

Lawn, G. 2004. Improving public access to legislation: the New Zealand experience. New Zealand law librarians' conference 22-24 July 2004. http://www.nzllg.org.nz/Conferences.cfm [accessed 20 December 2005]

Legal and Constitutional References Committee, Department of the Senate (Australia). 2004. Legal aid and access to justice. Canberra: Senate Printing Unit

Legal Services Agency. 2005. Annual report 2004/2005. Wellington: Legal Services Agency. 
LIANZA. Access to information. 2002.

www.lianza.org.nz/about/governance/statements/accesstoinfo.html [accessed 13 March 2006]

Martin, P. and J. Foster. 2000. Legal information - a strong case for free content, an illustration of how difficult "free" may be to define, realise, and sustain. Conference on free information ecology. 31 March - 1 April 2000.

McKechnie, D. 2000. The virtual court library. Sixth AIJA biennial court librarians' conference. Sydney, Australia, 18 July 2000.

McKechnie, D. 2003. The use of the internet by courts and the judiciary: findings from a study trip and supplementary research. 11 International Journal of Law and Information Technology: 109-148

McMahon, T. 1999. Improving access to the law in Canada with digital media. 16 Government Information in Canada: http://www.usask.ca/library/gic/16/mcmahon.html [accessed 15 February 2006]

National Library of New Zealand. 2006. Changes to legal deposit.

http://www.natlib.govt.nz/en/services/5legaldeposit.html [accessed 3 June 2006]

New Zealand Law Commission. 2004. Delivering justice for all: a vision for New Zealand's courts and tribunals. Report 85.Wellington: New Zealand Law Commission

New Zealand Law Librarian's Group. 1994. Access to government and state information in New Zealand. New Zealand Law Librarian's Group Newsletter no. 30: 1-12

Parent, R. 2000. What's so special about special libraries? 32 International Journal of Special Libraries: 212-221

Parker, Stephen. 1998. Courts and the public. Carlton, Victoria: Australian Institute of Judicial Administration Incorporated

Parliamentary Counsel Office. Public access to legislation project. Wellington, Parliamentary Counsel Office: www.legislation.govt.nz/aboutthis site.html [accessed 10 November 2005]

Parliamentary Counsel Office. 2005. Statement of intent for the period 1 July 2005 to 30 June 2008. Wellington: Parliamentary Counsel Office.

Perry, M. 1997. Roadblocks to LIINZ - problems facing public access to New Zealand's laws. [1997] Computerisation of Law Resources www.autlii.edu.au/au/other/CompLRes/1997/10/index.html [accessed 15 December 2005]

Poulin, D. 2003. Open access to law in developing countries. [2003] Computerisation of Law Resources. www.austlii.edu.au/au/other/CompL.Res/2003/1.html [accessed 19 November 2005] 
PriceWaterhouseCoopers. 1999. Parliamentary Counsel Office: improving public access to information. Wellington: Parliamentary Counsel Office

Scassa, T. 2000. The best things in law are free? Towards quality free public access to primary legal materials in Canada. 23 Dalhousie Law Journal: 301-336

Sims, L. 2004. Academic law library web sites: a source of service to the pro se user. 23 Legal Reference Services Quarterly: 1-28

State Services Commission. 1997. Policy framework for government-held information. www.ssc.govt.nz/documents/policy framework for government htm [accessed 10 December 2005]

State Services Commission. 2003. New Zealand E-government strategy. Wellington: State Services Commission

Staudt, R. and P. Hannaford. 2002. Access to justice for the self-represented litigant: an interdisciplinary investigation by designers and lawyers. 52 Syracuse Law Review: 1017-1039

Susskind, R. 2000. Transforming the law. Oxford: Oxford University Press

Swank, D. 2005. The pro-se phenomenon. 19 Brigham Young University Journal of Public Law: 373-386

The Working Group. Conference on delivery of legal services to low income persons: professional and ethical issues. 67 Fordham Law Review: 1813-1817

Tones, J. 2005. Copyright monopoly vs. public access - why the law should not be in private hands. 55 Syracuse Law Review: 371-394

Treadwell, J. 2000. Free access to the law: the strange case of New Zealand. 2000 Journal of Information, Law and Technology. www.law.warwick.ac.uk/jilt/00-1/treadwell.html [accessed 20 November 2005]

Westwood, K. 1998. Meaningful access to the courts and law libraries: where are we now? 90 Law Library Journal: 193-206

Woolf, H. 1996. Access to justice: final report to the Lord Chancellor on the civil justice system in England and W ales. London: Her Majesty's Stationery Office

WorldLII. Declaration on free access to law. 2002; 2003. www.worldlii.org.declaration [accessed 13 December 2005]

Wu, M. 2005. Why print and electronic resources are essential to the academic law library. 97 Law Library Journal: 233-256 


\section{Appendix 1: interview questions}

1. What is (approximately) is the size of your legal collection? (i.e. number of holdings including online, digital etc)

What do you hold in your collection as regards:

a) Statutory instruments

b) Case law collections

c) Secondary resources (Law Commission publications, journals, core texts such as Joseph, Todd, Sims etc)

What formats are your resources held in?

2. How many staff work in the library? Who is likely to deal with legal inquiries/lay litigants?

3. Who is the main user group/s the library? Who is the main user group/s of legal information? (if different)

4. How many users per day make use of legal resources? (approximately)

5. How frequently do you receive legal information inquiries from the general public? Are you able to differentiate between lay litigants and the general public?

6. How frequently do you receive inquiries from lay litigants?

7. What types of legal inquiries do you receive from lay litigants, and from members of the public? Which of these are the most commonly received? What kinds/types of information are sought?

8. What are the most highly used resources by lay litigants, and by members of the public, for inquiries requiring:
a) case law
b) legislation
c) secondary resources

9. Are these inquiries able to be answered by the library's resources or staff? If not, what do you recommend to users?

10. Are you lacking any legal resources to be able to assist users? If so, what, and for what reasons do you not hold these resources? i.e. money, space, training, useability

11. Do you encounter other problems in dealing with lay litigants or members of the public? If so, what?

12. Do you have any policies in place for dealing with lay litigants or members of the public who are seeking legal information?

13. If you generally allow lay litigants or members of the public access to your library, are any restrictions placed upon their them -i.e. use of particular resources or types of 
resources (such as databases or closed reserve items); the ability to print or photocopy; use of reference services etc

14. Do lay litigants generally come in for a one-off visit, or do they require help/use of resources over an extended period? Is this different for members of the public more generally?

15. Is there anything your library has set up/done to assist lay litigants or members of the public? Any other resources you are aware of to help them, or other places you recommend they go for help?

16. Do you believe assisting lay litigants (or the public more generally) with their legal inquiries is a role for your library? 


\section{VICTORIA UNIVERSITY OF WELLINGTON \\ Te Whare Wänanga o te Üpoko o te Ika a Mãui

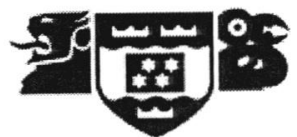

Letter of information: interview

\section{Lay litigants' access to legal information in libraries}

To

I am a student in the Masters of Library and Information Studies programme at Victoria University of Wellington. As part of the coursework for this degree, I am undertaking a research project to examine the types and amounts of legal information that lay litigants can access in libraries. With this information I hope to establish the current situation in New Zealand as regards access to legal information from libraries, and to highlight areas of concern.

To gather information I intend to conduct interviews with librarians from university law libraries, district law society libraries and public libraries in Christchurch and Wellington. Your participation in this study would be greatly appreciated.

Interviews will be conducted in person, at your convenience. They will be tape-recorded for later transcription. If at any time you wish to stop the interview you may do so, and resume at a later date, or not at all. If you wish to withdraw the information you have provided you may do so in written or verbal form before the $12^{\text {th }}$ June 2006. If you wish to view a copy of the interview transcript before its analysis, you will be given this opportunity. Your consent to the interview process will be granted by signing a consent form at the interview. I have received ethical approval from the Informatics Human Ethics Committee of Victoria University of Wellington to carry out this research project. 
All information given during the interview will be kept confidential and in no way be attributed personally to you. Recorded interviews and their transcripts will be kept secure in a locked drawer. My supervisor, Alastair Smith (please see contact details below) and I will be the only people able to access the information. Upon completion of the project all physical documents will be destroyed.

It is also possible that the results of this research may be presented at a conference or published at a later date.

If you choose to participate, please contact me either by email or telephone as listed below.

A copy of the report will be deposited in the Victoria University of Wellington library. If you wish to receive a report summary at the completion of the research, please contact me at the address below.

If you have any questions or would like to receive further information about this project, please contact me or my supervisor at:

\section{Investigator:}

Angela Blake

Ph: 044945513

Email: blake@crownlaw.govt.nz

\section{Supervisor:}

Alastair Smith

Ph: 044635785

Email:

Alastair.Smith@vuw.ac.nz

Thank you for your help.

Yours sincerely,

Angela Blake 
Appendix 3: Consent form

\section{VICTORIA UNIVERSITY OF WELLINGTON \\ Te Whare Wänanga o te Ūpoko o te Ika a Māui

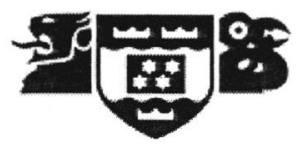

Consent form for interviewees

\section{Project title: Lay litigants' access to legal information in libraries}

I have been provided with a letter of information and have understood the nature and objectives of this research project.

I have had the opportunity to ask questions and clarify any aspects of the project that were not clear to me.

I agree to take part in an interview as outlined in the accompanying letter of information.

I understand that the interview will be recorded using an audio tape recorder but that I may request that the recording be stopped at any point during the interview.

I understand that I will have the opportunity to read and correct the transcription of the interview.

I understand that no data will be personally attributed to me.

I understand that I can withdraw from the research without explanation at any time prior to the scheduled start of the analysis of data, which is the 12th June 2006. I understand that the raw data for this research will be destroyed at the completion of the project.

I do/do not (circle one) wish to receive a summary of the findings which will be made available at the completion of the research

Name:

Email address (if requesting feedback):

Signed:

Date: 